\title{
Partnerships with Productive Sectors in Distinct Models of Brazilian Universities: A Comparative Case Study on UFABC and UTFPR
}

\author{
${ }^{1}$ Agnaldo da Costa, ${ }^{2}$ Luiz Alberto Pilatti, ${ }^{3}$ Celso Bilynkievycz Santos \\ 1 Agnaldo da Costa, Technology at Federal University of Technology - PPGECT, Paraná, Ponta Grossa , Paraná, Brazil, agnaldo2@ gmail.com \\ 2 Luiz Alberto Pilatti, Technology at Federal University of Technology - PPGECT, Paraná, Ponta Grossa , Paraná, Brazil, lapilatti@utfpr.edu.br \\ 3 Celso B. Santos, Technology at Federal University of Technology - PPGECT, Paraná, Ponta Grossa, Paraná, Brazil, bilynkievycz@ globo.com
}

Correspondence Author: : Agnaldo da Costa, Federal University of Technology - Paraná, Graduate Programme, Doutor Washington Subtil Chueire, 330- Ponta Grossa - Brazil

E-mail: agnaldo2@gmail.com

Received date: 29 August 2019, Accepted date: 19 November 2019, Online date: 22 November 2019

Copyright: (C) 2019 Agnaldo da Costa et al, This is an open-access article distributed under the terms of the Creative Commons Attribution License, which permits unrestricted use, distribution, and reproduction in any medium, provided the original author and source are credited.

\begin{abstract}
The aim of this paper is to compare which university models have the greatest connection with the productive sectors, the classic or technological model represented by the Federal University of ABC (UFABC) and the Federal Technological University of Paraná (UTFPR). The research hypothesis has the following formulation: Does the technological university model proposed by UTFPR have greater partnerships with the productive sectors when compared to the UFABC Classic? The database consisted of 151,115 UTFPR and 45,228 UFABC records comparing their technical and scientific publications from researchers between 2005 and 2017, analyzing the consultancies performed, research groups, technical papers, projects and research. This paper presents as a method of analysis the interpretation of the results of the samples of 151,115 UTFPR and 45,228 UFABC records. This method considers the percentage of performance of the two universities produced over the same period of time. The software used was R. (version 3.5.1). The results indicate that the UTFPR Technological has better performance compared to the classic Federal University of the UFABC in these 14 years of existence. The results are the basis for institutional policy evaluations and formulations in Brazil.
\end{abstract}

Keywords: Classical Universities, Universities of Technology, Productive Sector

\section{INTRODUCTION}

The creation of the only University of Technology in Brazil, the Federal University of Technology - Paraná (UTFPR) happened through Law 11.184 of 2005 (BRASIL, 2005a), which transformed the Federal Center of Technological Education of Paraná (CEFET-PR) into university. Today, UTFPR has 13 campuses in different cities in the State of Paraná, and courses in Engineering, Technology, and Teaching. Its faculty consists of 2,549 professors, among which 1,730 are doctors. The institution offers 108 undergraduate courses and 19 technical courses and has 34,000 students. Besides, UTFPR offers 95 specialization courses, 58 master's degree courses, and 11 doctoral programs. This represents the most significant number of Engineering courses among Brazilian federal universities.

In Brazil, the emergence, structuring and consolidation of technological education is the result of the transformation of technical-vocational secondary education that, for an extended period, was characterized by its relationship with the productive sector, which historically marginalized it from superior education in Brazil (Bastos, 2015).

Romano (2005, p. 204) says that a university specialized in technological fields should concentrate its vocation as a technology producer, and reinforce it. This view agrees with Pilatti and Lievore (2018b), who identified, as the significant differential of the universities of technology (UT), the emphasis on the relationship with business. This connection includes internship, undergraduate works related to problem-solving, meeting the needs of industry and society, and the emphasis given to technological research. 
The foundations of the UT are characterized by a strong connection with the productive sectors, allied to the changes that occurred in the economy in the 21 st century, which changed the educators' thinking about professional formation (Delors et al., 1996). Lima et al. (2016) point out that those changes imposed on universities in the late twentieth century changed their mission of serving the 21 st-century society, that is, the society of knowledge, technology, and especially education.

Within a few years of existence, this university model has become nationally and internationally prominent. UTFPR, a university of technology (UT), is the 22nd most popular university in Brazil, according to the World University Rankings \& Reviews (Unirank, 2019). In the publication of scientific articles, it is in 34th place, with 1.12\% of national production, according to Jornal da USP (2018). At the international level, the British Times Higher Education magazine (THE, 2019) ranks, among the first places, two universities of technology, the University of Massachusetts and the University of California, both American. In the same ranking, when evaluating emerging countries, UTFPR appears tied with other institutions in position 351st.

In 2005, the Brazilian Government (Brazil, 2005) created the Federal University of ABC (UFABC), which was born with an orientation towards a new undergraduate model. Unlike UTFPR, the university model proposed by UFABC is committed to the evolution of the spirit, rather than meeting the material needs of consumers.

UFABC's courses are distributed in two campuses, i.e., Santo Andre and Sao Bernardo do Campo, in the State of São Paulo, belonging to the areas of Engineering, Exact and Earth Sciences and Teaching, and its faculty is made up of 661 professors, all of them having PhD. Also, UFABC provides 24 graduate academic programs and three professional master's degrees, besides the Industrial Academic Doctorate Program (DAI).

UFABC main characteristic is the integral and generalist formation, motivated mainly by significant current problems of science and humanity, which are interdisciplinary. Its main commitment to society is to reestablish the appreciation for scientific knowledge, with the intention of demonstrating that such knowledge should not be linked only to market demands, but, above all, to the evolution and illumination of the human spirit (UFABC, 2019). In its Institutional Development Program (PDI) 2013-2022, the identification of priority themes that the university should address is seen as fundamental, but UFABC understands that it is essential to maintain openness to the diversity that characterizes the university environment.

Although there are core themes that materialize the main challenges of science, technology, and innovation, UFABC may prioritize some of them, avoiding rigidity around those themes or areas, and retaining some flexibility not to incur excessive expertise. Also, it proposes to prevent an exclusive orientation to applied themes, making similar efforts in basic and fundamental research (UFABC, 2013).

This paper analyzes, then, the scientific productions linked to partnerships with the productive sectors established by these two distinct university models. The theme is of great importance and urgency for contemporary society and public policies in Brazil. In this context, the research problem is represented by the following key question: What are the differences between the UTFPR technological model and the UFABC classic model, when comparing their links with the productive sectors?

Research projects, research groups, journal articles, academic advising, advisory services, processes or techniques, and products were defined and extracted from the researchers' Lattes curriculum.

This work is organized in three parts: the first provides a brief overview of the emergence of classical and technological universities, and the importance of partnerships with the productive sector; the second presents the methodology used for data comparison; the third shows the results and discussions about the differences found between the two universities studied. The research results can be used in institutional evaluation processes and the formulation of public education policies helping in the decision making of educational managers.

\section{MATERIALS AND METHODS}

According to Gil (2008), the methodological approach of this research can be exploratory. The procedures and techniques applied to characterize it as bibliographic research, which uses technological resources, such as software, to identify and select scientific articles from the Lattes Platform.

\subsection{Problem delimitation}

Regarding the limitation of this work, we can highlight that only the productions registered in the researchers' curriculum were analyzed. Lattes Platform data analysis was carried out between May and July 2018. Around 90\% of UFABC researchers' resumes were updated in the last 6 months, and 79\% of UTFPR researchers' resumes.

\subsection{Statistical Techniques}

In order to compare the universities regarding the categorical variables raised from the databases, the chi-square and simulated chi-square tests were used (Agresti; Kateri, 2011). To analyze the universities considering the numerical variables raised from the databases of the same section, the Mann-Whitney test (Hollander; Wolfe, 1999) was used.

\section{RESULTS AND DISCUSSION}

The intensification of interactions between universities and companies has been incorporating each year new means and institutional mechanisms for the dissemination of technology and knowledge. This points to a process characterized by bilateral flows of knowledge and techniques (Meyer-Kramer, Schmoch, 1998). This interaction has as its main objective to boost the 
economic and social development that characterized the developed countries from the mid-twenties (Etzkowits, Leydesdorff, 2000; Audy, 2011).

The UTFPR model aims to develop a technological education, linking the two extremes of the academic system, that is, the university and the labor market. According to its Institutional Pedagogical Political Project (PPI), such technological education should involve the articulation between research, teaching and extension activities, based on technological teaching (UTFPR, 2007, p. 61). On the other hand, despite adopting a humanistic model, UFABC recognizes the need to establish partnership and collaboration relationships with the productive and industrial sectors for the training of its students (UFABC, 2013-2022). In this context, for a comparison between the two universities, the proportion of professors was taken into account, considering, for UTFPR, 2,598 researchers, and, for UFABC, 661 researchers.

The Lattes Platform represents the National Council for Scientific and Technological Development (CNPq) experience in integrating databases of curriculum and of science and technology institutions into a single information system, whose current importance extends not only to CNPq fomentation operational activities but also to fomentation actions of other federal and state agencies.

The purpose of advising, consulting and analyzing technical processes is the provision of services by researchers to companies related to trade, service, industry and agribusiness, whether local, regional or international. The advising is characterized by being a specialized service that aims to assist the client in a technical need. In this sense, the company that hires a researcher's advisory service has the advantage of saving time and performing a specialized technical service.

The consulting and analysis of technical processes intends to making a diagnosis, in which the researcher monitors the reality of the company and, from that diagnosis, proposes solutions with the objective of increasing productivity or business improvement.

A total of 3,515 advisings, consultancies and analysis of technical processes performed by UFABC were found, being $750(21.1 \%)$ performed in companies. From UTFPR 10,824 were extracted, 2,547 (23.5\%) with links to companies. Although UTFPR has more studies compared to UFABC, the differences between them are not significant, being only $2.4 \%$. These results show that the researchers of the technological model of UTFPR do not have prominence in relation to the participation in the processes of the companies of the productive sector.

The CNPq Research Groups Directory gathers information about the research groups active in the country, including researchers, students, technicians, ongoing research lines, scientific, technological and artistic production. Despite being characterized by an optional information base, the universe covered by it is increasing, which means a relative representativeness of the national scientific community (Carneiro, Lourenço, 2003). Regarding the research groups considered in this study, a discrepancy with the amount presented by the DGP/CNPq (2019) occurred, because all groups were considered, regardless of their situation: certified, excluded, and not updated.

When analyzing the research groups by great area, as shown in Fig. 1, the Engineering and Human Sciences areas have the highest percentages of researchers at UFABC, what highlights the Humanities, reinforcing its characteristic of classical university in the training of researchers. At UTFPR technology, the predominant areas are Engineering and Exact and Earth Sciences. Although both universities adopt different models, the largest research groups are from Engineering.

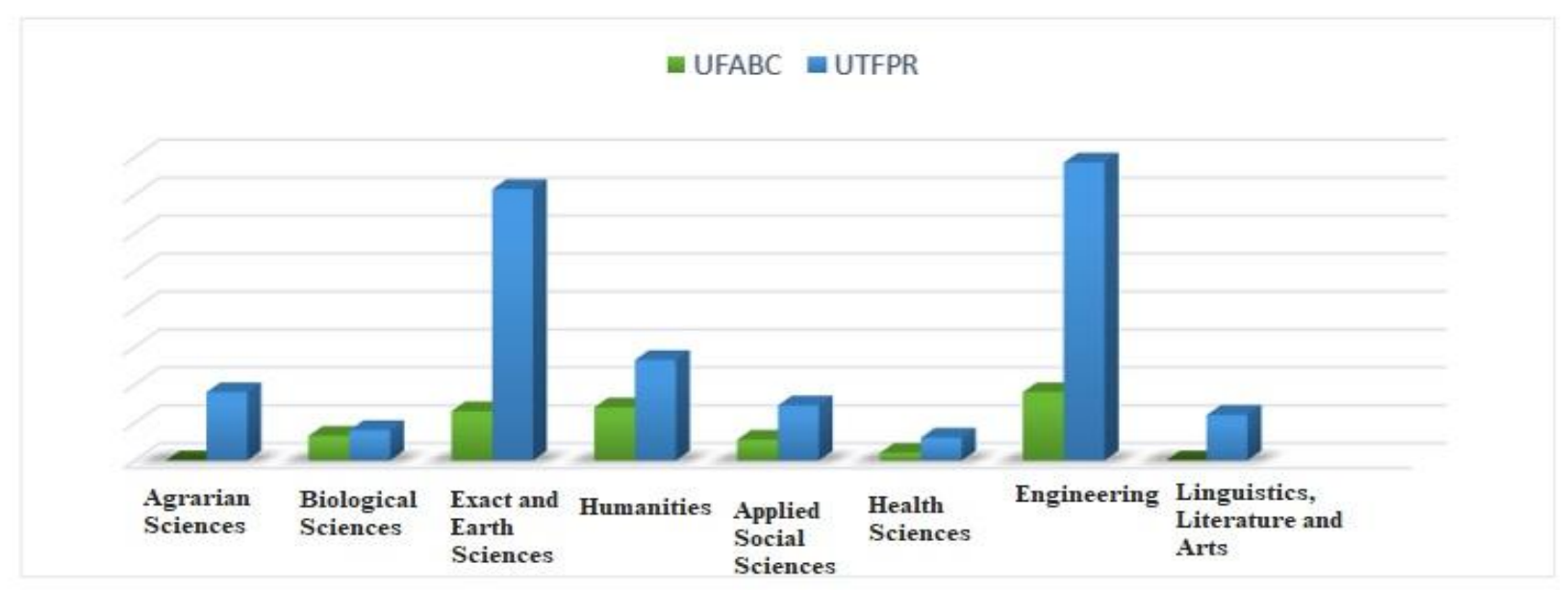

Fig. 1:Division of UTFPR and UFABC research groups by great area

Table 1 presents the results of the 256 research groups analyzed. Data show that $21(8 \%)$ of the UFABC groups carried out projects involving companies linked to the productive sectors.

For UTFPR, 738 research groups were found, among which 74 (10\%) groups established partnerships with the productive sectors. Proportionally, UTFPR had a higher percentage of research groups that partnered with companies, while UFABC had a higher percentage of research groups that had links with universities. Research groups allow researchers to build a solid network of contacts with other researchers for a purpose. This network may involve public and private sector companies, but data show that on average only $10 \%$ of the research groups created have partnered with the companies. 
Research projects are linked to university extension activities and are divided into technological development, research, extension and others. Figure 2 shows that UFABC has $77.61 \%$ of its research projects focused on research, $14.35 \%$ on extension, and $5.14 \%$ on technological development.

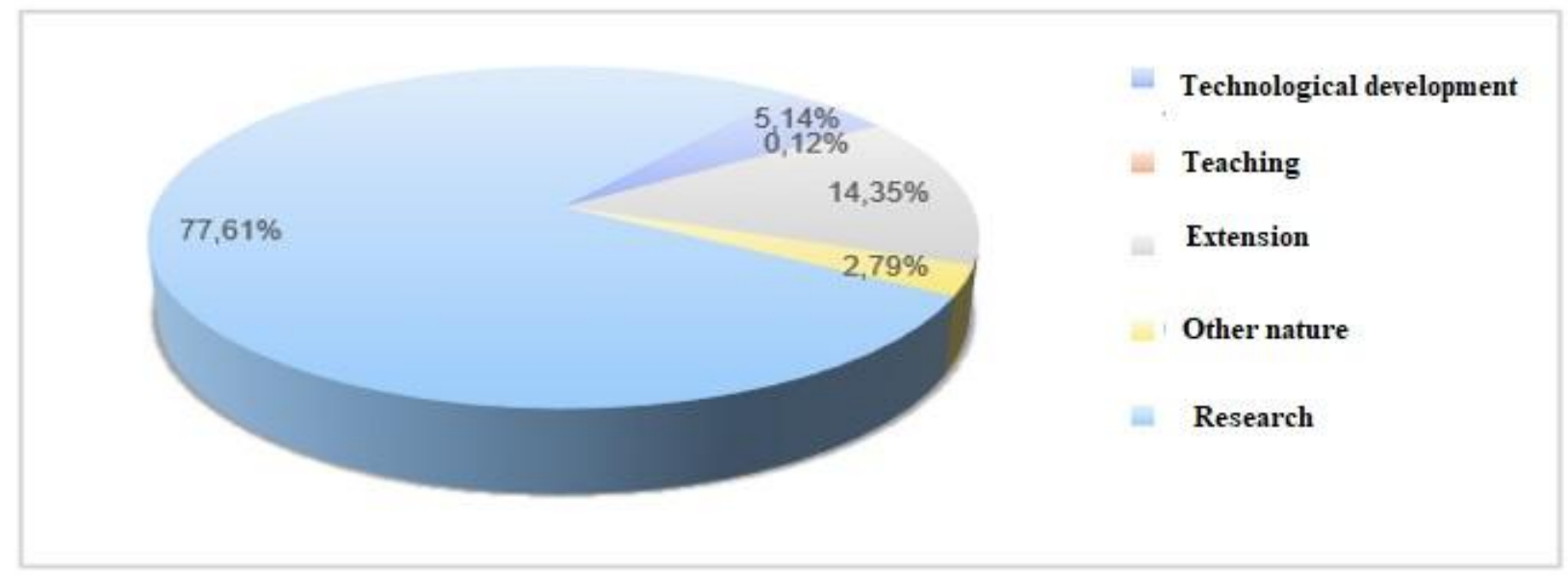

Fig. 2: Areas of Research Projects of the Federal University of ABC, sorted by Technological Development, Teaching, Extension, Research and Other Natures

This research found that $62.13 \%$ of UTFPR projects are research-oriented, $26.84 \%$ are extension-oriented, and $6.42 \%$ related to technological development. Comparing the two universities, it is possible to state that their differences are centered on research, extension and technological development, with UFABC having its differential in study and UTFPR having it in extension, but both concentrate their highest percentages in academic research.

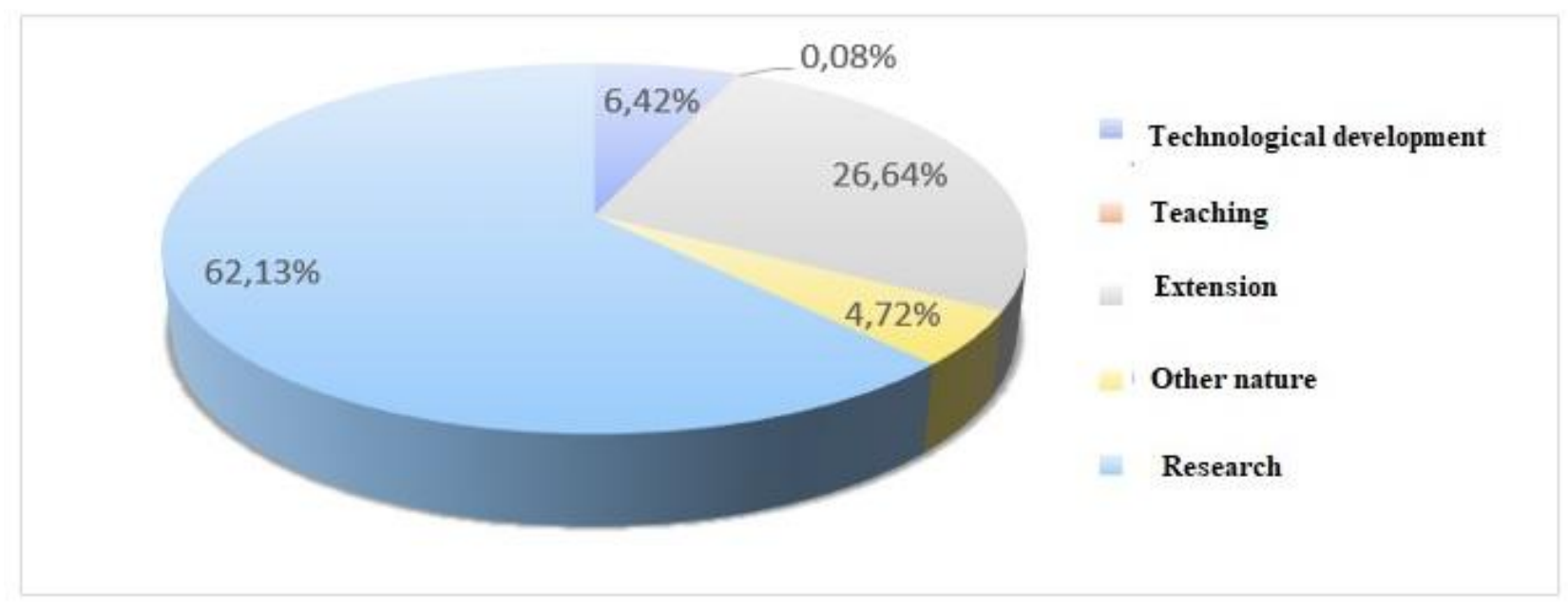

Fig. 3: Federal University of Technology of ABC research projects division by Technological Development, Teaching, Extension, Research, and Other Natures

UTFPR has 15,893 research projects, $147(0.92 \%)$ related to companies in the productive sector, while UFABC has 4,279 projects, $27(0.40 \%)$ carried out with the productive sector. The differences between the two concerning partnerships with companies, as shown in Table 1, show that UFABC has more projects per professor in technological development research with the productive sector, while UTFPR has a higher percentage of extension, research and other projects linked to the productive sector. Despite this result, we deduce that extension, which could be the differentiating factor of UTFPR concerning UFABC, is UTFPR biggest challenge.

The differential of technological universities around the world is the emphasis on relationships with the industrial sector and the emphasis on applied and technological research and extension projects, which focus less on the science-push model and more on the market-pull model (Pilatti; Lievore, 2018).

The technical papers registered in PL by researchers from both universities refer to the participation in various events involving teaching, scientific productions and technical opinions, in companies in the productive sector or in the educational area. In order to assess the data registered, the works were divided into the following categories: article evaluator, education evaluator, education consultant, education expert, book reviewer, productive sector work, and others. Taking into account all the technical works, we found 2,467 works by UFABC researchers, 88 (3.5\%) with companies in the productive sector. At UTFPR, there are 8,721 technical works, $502(5.75 \%)$ of which related to companies. 
The undergraduate work advising is an opportunity for students to get in touch with the job market through internships. UTFPR prioritizes the French model, in which engineering students undertake three mandatory full-time internships in companies strategically chosen by the university, accompanied by the internship advisor professor. In 2018, UTFPR had an agreement with more than 10,500 companies related to commerce, industry, services and other affiliated institutions.

While UTFPR prioritizes student mandatory internships in the fields of engineering and technology, UFABC focuses on international mobility for undergraduate and graduate students, encouraging students through projects that are not necessarily internships. Thus, it gives priority to scientific initiation, research, academic monitoring, among others (UFABC, 2013). This shows that UFABC encourages students to a more generalist, integral formation, focused on current problems of science and humanity, which are characterized as interdisciplinary, aiming at the structure of the whole, while UTFPR has its principles in the formation for the job market.

Regarding advising for final work related to the productive sectors, 12,593 advisings for UFABC and 54,240 advisings for UTFPR were computed. Although very small, there is a difference in the percentage of the type of orientation, which at UFABC focuses on undergraduate and master students when compared to the percentage of UTFPR. However, UTFPR stands out in the undergraduate student advising, when compared to UFABC. Confronting the data, we realize that UFABC has more doctoral, masters and postdoctoral supervision than UTFPR, a factor that significantly boosts the quality of research and scientific publications, as well as confirms such quality.

From the total selected, only $618(5 \%)$ UFABC undergraduate, masters and doctoral students had partnerships with the productive sectors, while at UTFPR this number reached 4,319 (8\%).

Table 1: Links to the productive sector by the university and by variables of interest - New analysis

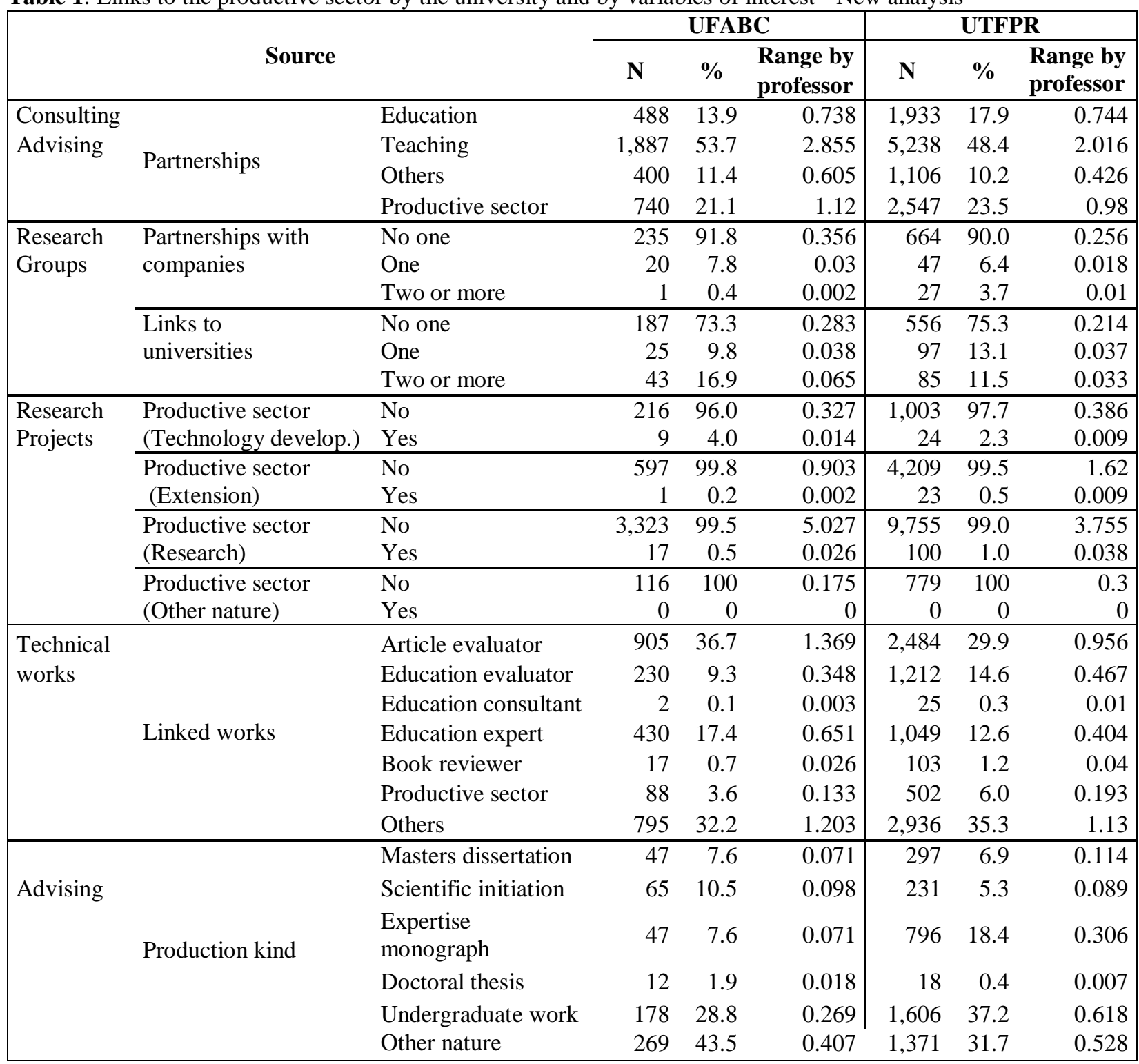

${ }^{1}$ Chi-Square Test; "Simulated Chi-Square Test.

The figures below represent figuratively the location regions of companies that have entered into agreements with universities at the local, regional, state and international levels. For advising, consulting, and research groups, partnerships 
predominate at local and regional levels. When analyzing the research projects of the two universities, the highlights are national and international projects, in which UTFPR has some advantage, on account of its partnerships with foreign companies.

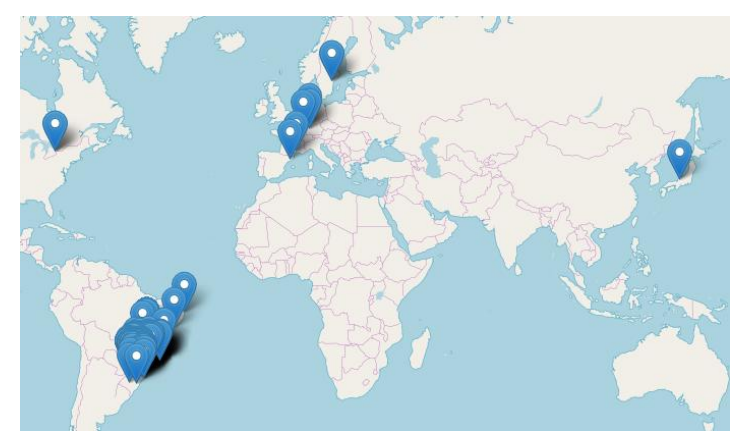

Fig. 4: A map with the location of UTFPR partner companies by project type (advisory, research groups, research projects)

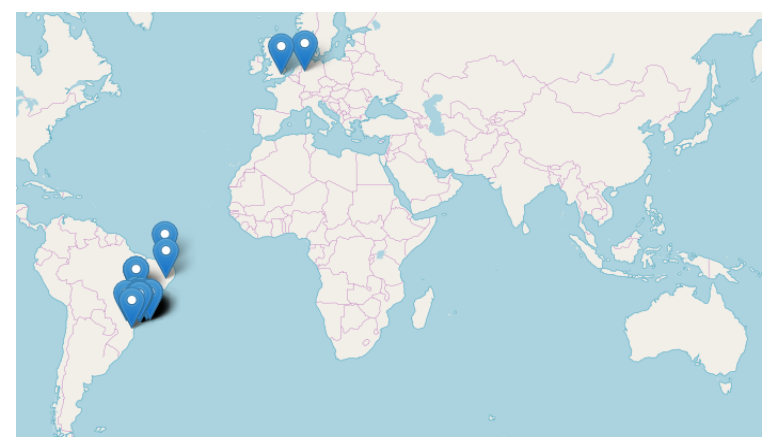

Fig. 5: A map with the location of UFABC partner companies by project type (advisory, research groups, research projects)

\section{CONCLUSIONS AND OUTLOOKS}

UTFPR is the only university of technology in Brazil. UFABC is the most influential young university that excels at the excellence of its research.

This research shows that, in its 14 years of existence, UTFPR has obtained better results in projects involving companies in the productive sector, compared to UFABC. Although the results favour UTFPR, it should be noted that there were no significant differences between the two university models. The technological university model was expected to point out the relationship with companies in the productive sector as compared to UFABC as a differential, since, in theory, the model presented by UTFPR distinguishes mostly in the university relationship with the market, however, in practice, UTFPR basic research does not show differential compared to UFABC's.

This finding is important because in Brazil there are other institutions such as the Federal Center for Technological Education of Rio de Janeiro (CEFET-RJ) and Minas Gerais (CEFET-MG), which claim to become universities of technology, as happened to UTFPR. These results can help formulate educational public policies that facilitate the approximation between universities and the productive sectors.

For this reason, the evaluation of models that have a strong connection with the market directly impact the economic development of the countries. Carayannis and Rakhmatullin (2014) reveal a tendency of modern universities to consider these relationships to be important because, in addition to fulfilling their traditional functions, each institutional sphere also assumes part of the other's role, filling gaps that arise when one sphere has limitations. From this perspective, in addition to their teaching and research activities, institutions should increasingly engage in technology transfer and business creation, encouraging entrepreneurship and thus accounting for some traditional industry role.

Our analysis suggests that the identity of scientific research at UTFPR is still under construction, and requires internal policies to further encourage technological research and more relationships with the industrial sector so that UTFPR can indeed to highlight in these areas.

Finally, we emphasize that a university of technology, according to the Latin American Network of Technological and Polytechnic Universities (2018), should not only be evaluated by partnerships with the productive sectors, but by a set of indicators, such as entrepreneurship, patenting, social and environmental responsibility, and an active link with the productive sectors. In this sense, this research does not focus on whether UTFPR is characterized as a university of technology or not; it presents its performance specifically in the links with the productive sectors. 
Citation: Agnaldo da Costa, et al., Partnerships with Productive Sectors in Distinct Models of Brazilian Universities: A Comparative Case Study on UFABC and UTFPR. Australian Journal of Basic and Applied Sciences, 13(11): 70-77. DOI: 10.22587/ajbas.2019.13.11.10

\section{REFERENCES}

Audy, J. L. Nicolas. Entre a tradição e a renovação: os desafios da universidade empreendedora.2006, p. 265 - 274. In: A universidade no Brasil: concepções e modelos / MOROSINI, Marília (Org.). Brasília: Instituto

Nacional de Estudos e Pesquisas Educacionais Anísio Teixeira, 2006, 297 p. DOI: https://doi.org/10.5007/19834535.2013v6n4p216

Agresti, A.; KateriI, M. Categorical Data Analysis. Gainesville, Florida: John Wiley, $2011 . \quad$ v. 45 DOI:https://doi.org/10.1007/springerreference_205246

Bastos, J. A. de S. Leão. O Papel dos Centros Tecnológicos. In: SILVA, Maclovia Corrêa da. Conversando com a tecnologia: contribuições de João Augusto Bastos para a educação tecnológica. 2015.

Brasil. Lei n. ${ }^{\circ}$ 11.145, de 26 de julho de 2005b. Institui a Fundação Universidade Federal do ABC - UFABC e dá outras providências. Diário Oficial da República Federativa do Brasil, Brasília, DF, 27 de jul. 2005, p. 1.

Brito Cruz, C. H., 2010. Ciência, tecnologia e inovação no Brasil: desafios para o período 2011 a 2015. Revista Interesse Nacional, 3(10): 1-22. Retrieved from https://www.ifi.unicamp.br/ brito/artigos/CTI-desafios-InteresseNacional07082010-FINAL.pdf on 11th February 2018.

Carayannis, E. G.; Rakhmatullin, Ruslan. The quadruple/quintuple innovation helixes and smart specialisation strategies for sustainable and inclusive growth in Europe and beyond. Journal of the Knowledge Economy, v. 5, n. 2, p. 212-239, 2014. DOI: https://doi.org/10.1007/s13132-014-0185-8

Carneiro, S. J., R. Lourenço, 2003. Pós-graduação e pesquisa na universidade. In Indicadores de ciência, tecnologia e inovação no Brasil, Orgs, Viotti, E. B., Macedo, M. Campinas: Editora da Unicamp, pp.169-227.

Castro, L. M. C., 2004. A universidade, a extensão universitária e a produção de conhecimentos emancipadores, In the Proceedings ofn the ANPEd, 27, Caxambu. Disponível: 〈http://www.anped.org.br/reunioes/27/início.htm>. Acesso em: 17 jul. 2017.

Cunha, L. A., 1986. A universidade temporã: da colônia à era de Vargas. Francisco Alves.

Clark, B. R., 2003. Sustaining change in universities: continuities in case studies and concepts. Tertiary Education and Management, 9(2): 99-116. Retrieved from http://dx.doi. org/10.1080/13583883.2003.9967096 on 10 th January 2018. DOI: https://doi.org/10.1080/13583883.2003.9967096

Delors, J. et al., 1996. Relatório para a UNESCO da Comissão Internacional sobre Educação para o século XXI. In Educação: um tesouro a descobrir. DOI: https://doi.org/10.29148/labor.v1i16.6504

Duméry, H., P. Gruson, R. Rémond, A. Touraine, 2017. Université. Encyclopædia universalis. Universalis Éducation. Retrieved from http://www.universalis.fr/encyclopedie/universite/ on 17th July 2019.

Drèze, J. H., J. Debelle, 1983. Concepções da universidade. Universidade Federal do Ceará (UFC).

Etzkowitz, H., 1998. As normas da ciência empreendedora: efeitos cognitivos das novas ligações universidade-indústria. Política de pesquisa, 27(8): 823-833

Etzkowitz, H., L. Leydesdorff, 2000. The dynamics of innovation: from National Systems and “Mode 2" to a Triple Helix of university-industry-government relations. Research Policy, 29(2): 109-123.DOI: https://doi.org/10.1016/s00487333(99)00055-4

Félix, G. T., 2008. Reconfiguração dos modelos de universidade pelos formatos de avaliação: efeitos no Brasil e Portugal. M. S. thesis, Universidade Federal do Rio Grande do Sul, Porto Alegre, RS.

Flexner, A., 1994. Universities: American, English, German. Transaction publishers. Oxford University Press.DOI: https://doi.org/10.1177/0270467696016001113

Guimarães, A. A., 2013. Robert Paul Wolff e o ideal da universidade. Revista Eletrônica Fafit/Facic, 4(1). Retrieved from http://www.fafit.com.br/revista/index.php/fafit/article/view/58 on 12th June 2019.

Gross, J. S., R. Gross, 2002. Propostas de diretrizes para uma nova concepção de universidade. Tuiuti: Ciência e Cultura, 28(4): 67-90. Retrieved from http://www.utp.br/tuiuticienciaecultura/FCHLA/FCHLA\%2028/PDF/art\%203.pdf on 20th October 2018.

Hollander, M., D. A. Wolfe, 1999. Nonparametric Statistical Methods. 2nd. ed. John Wiley \& Sons.

Kerr, C., 1982. Os usos da universidade: com post scriptum 1972. Universidade Federal do Ceará.

Lima, P. G., F. Castro, M. A. V. Carvalho, 2000. Caminhos da universidade rumo ao século XXI: pontos e estratégias para a sua orientação na visão de educadores brasileiros. Paidéia, 10(18): 8-27. Retrieved from http://www.scielo.br/scielo.php?pid=S0103-863X2000000100002\&script=sci_abstract\&tlng=pt on 08th February 2019. DOI: https://doi.org/10.1590/s0103-863x2000000100002

Meyer-Kramer, F., U. Schmoch., 1998. Science-based technologies: university- industry interactions in four fields. Research Policy, 27(8): 835-851. DOI: https://doi.org/10.1016/s0048-7333(98)00094-8

Morhy, L., 2003. Universidade na encruzilhada. Palestra. Retrieved from http://portal.mec.gov.br/sesu/arquivos/pdf/palestra6.pdf on 08 February 2019.

Nelson, R.R., 1990. Capitalism as an engine of progress. Research Policy, 19(3): 193-214. DOI: https://doi.org/10.1007/978-94009-1075-1_8

Paula, M. F. C., 2002. USP e UFRJ: a influência das concepções alemã e francesa em suas fundações. Tempo Social, 14(2): 147161. DOI: https://doi.org/10.1590/s0103-20702002000200008 
PilattiI, L. A.; Lievore , C. Universidades tecnológicas: o que induziu esse modelo universitário no Brasil. Revista Brasileira de Ensino de Ciência e Tecnologia, v. 11, n. 2, 2018. DOI: https://doi.org/10.3895/rbect.v11n2.8471

Prota, L., 1987. Um novo modelo de universidade. Convívio.

Reinert, J. N., C. Reinert, 2003. A universidade como modelo de estrutura organizacional. In the Proceedings of the Colóquio Internacional sobre Géstion Universitaria en América del Sur, Buenos Aires, Argentina. Retrieved from https://repositorio.ufsc.br/handle/123456789/116335 on 03rd February 2019.

Rossato, R., 2005. Universidade: nove séculos de História. Universidade de Passo Fundo.

Silva, E. W., 2003. Extensão universitária no Rio Grande do Sul: concepções e práticas. Porto Alegre. Doctoral thesis, Universidade Federal do Rio Grande do Sul, Porto Alegre, RS.

Silveira, Z. S., L. Bianchetti, 2016. Universidade moderna: dos interesses do Estado-nação às conveniências do mercado. Revista Brasileira de Educação, 21(64): 79-99. Retrieved from http://www.redalyc.org/html/275/27543071005/ on 10th February 2019. DOI: https://doi.org/10.1590/s1413-24782016216405

Singer, P., 2001. A universidade no olho do furacão. Estudos Avançados, 15(42): 305-316. Retrieved from http://www.scielo.br/pdf/ea/v15n42/v15n42a16.pdf on 15th February 2019. DOI: https://doi.org/10.1590/s010340142001000200016

The world university ranking -Latin American Ranking. Disponível em:

https://www.timeshighereducation.com/world-university-rankings/2019/latin-america-universityrankings\#!/page/0/length/25/sort_by/rank/sort_order/asc/cols/undefined>. Acesso em 14 ago. 2018.

Trindade, H., 1999. Universidade em perspectiva: sociedade, conhecimento e poder. Revista Brasileira de Educação, (10): 5-15. Retrieved from http://cienciaparaeducacao.org/eng/publicacao/trindade-helgio-universidade-em-perspectiva-sociedadeconhecimento-e-poder-anped-revista-brasileira-de-educacao-sao-paulo-n-10-p-5-15-1999/ on 10th February 2019.

Universidade Federal do ABC (UFABC). 2013. Plano de Desenvolvimento Institucional (PDI). Retrieved from http://www.propladi.ufabc.edu.br/images/pdi/livro\%20pdi.pdf on 26th October 2018.

Universidade Tecnológica Federal do Paraná (UTFPR), 2007. Projeto Político Pedagógico Institucional (PPI). UTFPR. Retrieved from http://www.utfpr.edu.br/ainstituicao/documentos-institucionais/projeto-politico-pedagogico-institucional-1 on 26th October 2018. 